\title{
Pencitraan radiologik CT-scan sebagai alat screening pasien untuk pemasangan implan gigi Radiologic imaging of CT-scan as a screener for patients in placing dental implant
}

\author{
Barunawaty Yunus, Syamsiar Toppo \\ Bagian Radiologi \\ Fakultas Kedokteran Gigi, Universitas Hasanuddin \\ Makassar, Indonesia.
}

\section{ABSTRACT}

The success of dental implant installment is determined by the condition of alveolar bone itself. Although there is no legal research of the dental implant treatment failure in Indonesia, but there are some reports which state that there is a lot of dental implant treatment failure happened which caused by the lack of appraisal of the quality and quantity of the alveolar bone image which is accurate and optimal in the usement of radioghraphy units. But as the time goes, the public needed of dental implant treatment begins increased. The purpose of this paper is to introduce the CT-Scan with Hounsfield Unit sofe ware as a screener to patients for dental implant placement with value bone mineral density (BMD). The measurement of BMD on alveolar bone before surgery for dental implant installment must describe local condition and then compared the size with the diameter of dental implant. From the discussion, it can be concluded that with using the CT-Scan, somebody can be stated get requirement or not for dental implant placement.

Key words: CT-scan, Hounsfield unit, bone mineral density, dental implant

\begin{abstract}
ABSTRAK
Keberhasilan pemasangan implan gigi sangat ditentukan oleh kondisi tulang rahang itu sendiri. Walaupun belum ada penelitian resmi tentang kegagalan perawatan implan gigi di Indonesia, namun ada beberapa laporan yang menyatakan bahwa banyak terjadi kegagalan pemasangan implan gigi disebabkan karena kurangnya penilaian kualitas dan kuantitas tulang rahang yang akurat dan kurang optimal pada penggunaan alat radiografi. Namun seiring dengan waktu, permintaan masyarakat akan kebutuhan perawatan implan gigi mulai meningkat. Penulisan artikel ini ditujukan untuk memperkenalkan CT-Scan dengan perangkat lunak Hounsfield unit sebagai alat screener pasien untuk pemasangan implan gigi dengan menilai densitas mineral tulang (DMT). Pengukuran DMT pada tulang rahang sebelum dilakukan pembedahan untuk pemasangan implan gigi harus dapat menjelaskan keadaan lokal yang kemudian dibandingkan ukurannya dengan ukuran diameter implan gigi. Dapat disimpulkan bahwa dengan memanfaatkan peralatan CT-Scan, seseorang dapat dinyatakan memenuhi syarat atau tidak untuk pemasangan implan gigi.
\end{abstract}

Kata kunci: CT-scan, Hounsfield unit, densitas mineral tulang, implan gigi

Koresponden: Barunawaty Yunus, Bagian Radiologi Fakultas Kedokteran Gigi, Universitas Hasanuddin, Jl. Kandea No. 5, Makassar, Indonesia.Email: barunawaty@yahoo.com 